\title{
Legal fact based on occurrence civil rights and obligations.
}

\author{
Bakhromjon Topildiev, Tashkent state University of Law Republic of Uzbekistan \\ Rustam Khursanov, Tashkent state University of Law Republic of Uzbekistan
}

\begin{abstract}
In civil law, the institution of "the emergence of civil rights and obligations" has its own characteristics. Civil rights and obligations differ from other types of legal relations in their origin and, moreover, in civil legal relations. These differences are associated, firstly, with the state of civil relations as "normal relations" and, secondly, with the fact that, in contrast to the rights and obligations in the field of law with a protective function, civil rights and obligations often arise from legal actions ... In civil law, which has a dispositive focus, the set of rights and obligations belonging to subjects, forming the content and structure of this area of law, necessitates determining the grounds for their formation and determining the types of these grounds.
\end{abstract}

Keywords: trust, trust management, legislation, property, legal system, owner, element, law, contract. Received: 08.12.2020 Accepted: 19.01.2021 Published: 03.02.2021

\section{Introduction}

In legislation, the concept, legal facts, was first reflected in the German Civil Code of 1900, often referred to as the German Civil Code. Romanistic., Predominantly German and Italian, developing the traditions of pandectics (G. Puchta, F. Savigny, B. Windsheid, E. Becking, D. Burcardi, A. Heimberger, E. Helder, etc.) devoted and pays much more attention. Especially noteworthy are the works of such authors as E. Betty, V. Shaloya, B. Bjondi, P. Vochi, P. Bonfante, B. Albanese. Among modern novelists, the first place belongs to the scientific researches of M. Talamanca, M. Marrone, V. Giuffre, N. Scapini, D. Diosdi, etc. The named scientists investigate the issues of general concepts of legal fact and composition, give their classifications, analyze the role of legal facts in ensuring rights and obligations of subjects of legal relations, etc..

In France, matters of legal fact are mainly dealt with in civil law courses in connection with the problem of the arising of obligations. Assessing the state of affairs in this area, the famous French jurist $\mathrm{L}$. Julio de la Morandière wrote: "Each of the circumstances behind which our law recognizes the force of the factor that generates the law, makes its transition and its termination, is determined by special rules, and our law does not proceed from any general theory of legal facts».

In the theory of law, circumstances, events, actions of persons who create, change and terminate legal relations are called legal facts. Legal facts are considered as the basis for the formation of any legal relationship.

As noted in most of the legal literature, the norms (laws) of civil law by themselves do not create civil law relations. The emergence, change or termination of civil relations is determined by certain circumstances. Consequently, cases related to the establishment, change and termination of legal relations are called a legal fact.

According to N. D. Egorov, in this case, legal facts serve as a link between legality and civil law relations. Without legal facts, no civil law relationship can be created, changed or terminated.

Commenting on the article $8 \mathrm{GK}$ RUz (Basics of civil rights and obligations), Raxmonkulov X.R. konstatiruet sleduyushchee: dannaya statya daet osnovaniya dlya vozniknoveniya grazhdansko-pravovyx otnosheniy. Under such osnovoy formirovaniya grazhdanskix prav i obyazannostey ponimayutsya tak nazыvaembe yuridicheskie fakty okrujayushchey nas deystvitelnosti.

I.B. Zakirov, continuing his views on civil rights and obligations, stressed that for the existence of civil law relations, certain circumstances must be created that are directly provided for by legal norms, and are also not provided in accordance with the general principles and content of civil law.

In our opinion, the designation of the grounds for the emergence of civil rights and obligations by the general term "legal facts" allows in a certain way to link these grounds with a general criterion - the state of legal consequences. Such a legal consequence is determined by the rule of law, and a legal fact, that is, the emergence of grounds for the emergence of civil rights and obligations established by law, is governed by the rule of law.

In the legal literature, Y. Tkachenko expressed her opinion regarding the formulation of the concept of legal facts: "Legal facts are understood as those facts with which the rule of law associates the occurrence of the legal consequences indicated in it." Developing such a concept in his other work, Yu. Tkachenko writes that "legal facts are such circumstances with which the law associates the occurrence of certain 
legal consequences." Exploring this problem in her works, she rightly notes that in the literature, legal facts are mainly defined as circumstances leading to the emergence, change or termination of legal relations. In her opinion, this definition is too narrow, since it does not take into account that legal facts can also give rise to legal capacity, legal capacity and subjective rights and legal obligations that do not correspond to each other..

The basis for the emergence of civil rights and obligations is the result of a certain action, and it is this action that is a legal fact. For example, a contract is known to be an agreement between two or more persons. It is clear and obvious that the legal relationship between the parties in connection with the transfer of goods, the performance of work, the provision of services or the payment of money arise from contracts. However, it is this situation that becomes the basis for the formation of civil law relations, that is, a legal fact, through internal legal relations, such as making an offer and accepting an item. Therefore, as V.A. Belov, a legal fact is an intermediate link between civil law in the objective sense (the norm of civil law) and subjective law. A legal fact guarantees that abstract legal norms are applied to a specific situation and allows you to determine the content of a specific legal relationship.

Article 8 of the Civil Code lists the following grounds for establishing civil rights and obligations:

1) contracts and other agreements provided for by law, as well as contracts and other agreements not provided for by law, but not contradicting it;

2) documents of state bodies or self-government bodies of citizens provided by law as the basis for the emergence of civil rights and obligations;

3) a court decision on the establishment of civil rights and obligations;

4) as a result of the acquisition of property on the grounds permitted by law;

5) as a result of the creation of works of science, literature, art, inventions and other intellectual activity;

6) as a result of causing harm to another person;

7) as a result of unjust enrichment;

8) as a result of other actions of citizens and legal entities;

9) as a result of events related to legislation with the occurrence of civil law consequences.

Legal facts not only create civil rights and obligations, but also change and cancel them, in other words, legal facts not only create certain legal relationships, but also affect their implementation. However, the function of legal facts to create legal relationships is primary, and legal facts that create legal relationships are also considered to have the ability to change or cancel them.

The presence of a single legal fact is not enough for the formation of civil law relations. In some cases, a legal structure is required, which consists of a combination of several legal facts. Legal content is a set of legal facts necessary to create legal consequences established by the rule of law.

According to O.A. Krasavchikova, the fact is understood as actions that are not important for the law. A legal fact is the essence of a civil dispute. If the fact is called legal, the content is practical, their combination, the complex (content) has no legal meaning, has no practical nature, gives rise to delusion. In fact, a fact has legal significance when it is in a specific context.

A complete and comprehensive description of the types of legal facts in civil law can be performed using a rigid logical system, that is, classification. The classification of legal facts based on the will of a person is the basis of classification in the theory of legal facts. Hence, since legal facts are expressed as actions aimed at creating, changing and abolishing rights and obligations, will becomes fundamental and decisive. According to O.A. Krasavchikov, the main classification criterion is the classification of legal facts according to the criterion of "free will", which takes into account the characteristics and essence of the subject, classifies the legal nature and essence of each type of legal facts. At the same time, legal scholars classify legal facts according to other criteria. These criteria include: classification by legal consequences, by the form of their manifestation (legal actions and the form of their expression), upon completion of a specific event

However, the "free will" classification is not universal. It is impossible to determine a single general (universal) criterion for the classification of legal facts, therefore such a classification requires the use of several criteria (criteria) simultaneously. O. A. Krasavchikov criticized the attempts of lawyers to use two or more criteria simultaneously to create a unified classification, noting that the value of any classification, including the classification of legal facts, lies in the fact that all classified events are systematized according to systematization and are pre-selected divisions. Otherwise, the classification loses its scientific character and practical significance. Therefore, "versatility" cannot be considered a single criterion, although it is based on a fairly polished kiss. In particular, the classification of "will" on the use of two characters in one document at the same time is not justified. Emphasizing the validity of these views, the classification of legal facts is based on various criteria, and there are many classifications in the legal literature defining specific (in some cases unique) criteria.. The choice of classification criteria is determined by the objectives of the study. For example, legal facts are classified according to their 
objective form. Obviously, legal facts reflecting a real life situation are not always documented, and their designation can be confirmed in various forms: documents, magnetic records, photographs, and so on. Other criteria can also be recognized as the basis for the classification of legal facts, and therefore in civilization there are other criteria for the classification of legal facts. However, in most cases, lawyers do not take into account that the classification is proven in practice, is targeted and relevant on the basis of facts. It is impossible to consider and analyze all types of classification of legal facts within the scope and scope of this study. Consequently, the analysis of legal facts can be continued on the basis of consideration of the classification criteria proposed by S.S. Alekseev:

1) on the consequences of a legal fact;

2) by the forms of legal facts (positive and negative);

3 ) the nature of the action of a legal fact (limited (one-time) facts and facts of a specific case);

4) the nature of the connection of facts with the individual will of individuals (legal events and lawsuits). Depending on the consequences, legal facts are divided into the following types: law-making, law-changing and law-terminating (any civil legal relationship, as a rule, arises, changes and stops in the course of its action). The legal facts that give rise to law include actions that ensure the formation of civil law relations. Usually these are civil law agreements, compensation for damages, public documents, etc. Legal facts that change the law change the existing civil law relations, that is, the subjective structure or content of legal relations changes, but at the same time the existence of civil law relations remains. In legal law, actions that lead to the complete termination of legal relations are considered legal facts that invalidate the right to legal force. Such legal facts may include: the destruction of property marked with special signs, the consumption of goods, the fulfillment of obligations, the death of a citizen, the fact that the debtor and the creditor remain one person, the consent of the parties to terminate the contract, etc. The legal literature states that legal facts should be divided into types that create, modify and abolish the law, because in this situation one legal fact can simultaneously act as both a source of facts and a law. At the same time, it should be recognized that there is controversy in the literature about the existence of other types of legal facts in addition to the types of legal facts that create law, alter law and annul law. Proponents of this point of view point to another type of legal fact, calling it "an obstacle to the law" and cite as examples of coercion, deception or error in the transaction, the fact that the transaction was made for the purpose of fraud and deception, and a number of other cases. Indeed, legal facts cannot be clear and uniform for those species that create law, change law, abolish law, and obstruct law. Therefore, such a grouping cannot be a means of systematizing a legal fact, and any classification is considered a systematization. Based on these circumstances, it can be concluded that the division of legal facts into types that create a law, change the law, cancel the law, hinder the law cannot be classified according to the criteria of the consequences of legal facts. However, there is no doubt that the legal facts in relation to each other create rights and obligations in some cases, invalidate the rights and obligations in other cases and prevent the emergence of other legal facts in the third case. It should be borne in mind that different facts perform different dynamic functions of legal facts, that is, the influence of legal facts on each other and on civil law relations. For example, in the literature, terms that represent a type of legal fact are divided into terms that simultaneously create a right, change a right, and cancel a right.

Analysis of legal facts allows you to determine the relationship of legal facts in terms of their mutual legal structure and the impact of one legal fact or a number of legal components on civil law relations. In other words, it becomes important to study the function of legal facts. Therefore, as recognized above, one legal fact can simultaneously perform several functions. In particular, the legal facts are the simultaneous cancellation of the right and the creation of the right; or creation of a right, change of right and cancellation of a right; or restoration of law and lawmaking; or may perform a lawmaking and prohibiting function. That is, one legal fact can simultaneously perform two or more functions. However, the classification of legal facts according to the function they perform, as practice shows, is not promising. For example, as a legal fact, the functions performed by the pledge can be divided into three: proof (proves the fact of the conclusion of the contract), payment (this is part of the payment to be made under the contract) and security (ensures the fulfillment of the obligation). It is difficult to classify zakat on the basis of its function and, in our opinion, it is impossible to accomplish this task. This does not mean that there is no need to classify according to the effect of legal facts. The classification criterion should be recognized not only the function performed by a legal fact, but also the legal consequence created by it. Such consequences are divided into two types:

- movement of civil law relations;

- other legal consequences.

As noted above, legal facts affect not only the action of civil legal relations (its occurrence, change or termination), but also the various consequences of manifestation of the subjectivity of civil law, as well 
as the consequences of actions to protect violated or disputed subjective civil rights. Legal facts about the legal consequences arising from this situation are divided into:

- influencing the law (as a rule, they are also called the creators of the law - but its content is not clearly expressed in the name);

- positive in relation to the law (do not affect the operation of legal relations, but create other legal consequences associated with the law).

In conclusion, when analyzing a legal fact, proceeding from its understanding as a specific life situation, the following signs should be present: first, the fact that a given life situation has arisen; secondly, the possibility of legal consequences. The concept of a legal fact in civil law includes the following definition:

- in civil law, a legal fact is understood as a real situation that, under the influence of a rule of law, generates legal consequences in the field of civil law relations.

\section{References}

${ }^{1}$ Vitushko V.A., Continuous theory of legal facts // Problems of legal regulation of economic activity of the economy in transition: materials of the scientific-practical conference Minsk. 2002 p. 3-9

${ }^{1}$ Morandier L, French Civil Law - M: foreign. literature, 1958.

${ }^{1}$ Topildiev B.R. Civil law regulation of trust management of property.-Tashkent: Institute of Philosophical Law, 2009.-31 p.

${ }^{1}$ Civil law: Textbook .: In 3 volumes. Vol. 1.-6th ed., Revised. and additional / ND Egorov, IV Eliseev et al .; Editor-in-chief A.P. Sergeev, Yu.K. Tolstoy.-M .: TK Welby, Prospect Publishing House, 2003.-103 p .; Zokirov I.B. Civil law. Part I.-Tashkent: TSU, 2009.-126 p

${ }^{1}$ Civil law: Textbook .: In 3 volumes. Vol. 1.-6th ed., Revised. and additional / ND Egorov, IV Eliseev et al .; Editor-in-chief A.P. Sergeev, Yu.K. Tolstoy.-M .: TK Welby, Prospect Publishing House, 2003.-103 p.

${ }^{1}$ Commentary to the Civil Code of the Republic of Uzbekistan. Volume I.-Tashkent: 2010. "Vector-Press" publishing house, $-25 \mathrm{p}$.

${ }^{1}$ Zokirov I.B. Civil law. Part I.-Tashkent: TSU, 2009.-126 p.

1 "Legal facts in the mechanism of termination of civil relations" Kostruba A.The. Monograph, Kiev. p. 23

${ }^{1}$ Belov V.A. Civil law: General part: Textbook. -M .: JSC "CenterInfoR", 2002.-188 p.

${ }^{1}$ Krasavchikov OA Legal facts in Soviet civil law. - M .: Legal literature, 1958.-60 p.

${ }^{1}$ Krasavchikov OA Legal facts in Soviet civil law. - M .: Legal literature, 1958. -S. 82.87.

${ }^{1}$ In the same place. P. 85-86.

${ }^{1}$ Yakushev P.A. Legal acts and actions as the basis of legal relations. -Vladimir: VGPU, 2003.-P.27-39 .;

Goryunova E.N. Dialectics of legal facts in the system of legal norms. - Belgorod: Vezelitsa, 2002.-P.79-114.

${ }^{1}$ Alekseev S.S. General theory of socialist law.-Sverdlovsk: 1964.-P.157-171 ;; Alekseev S.S. Problems of the theory of law. Vol. 1. -Sverdlovsk: 1972.-P.341-370.

1 Barinov O.V. Classification of legal facts and their meaning in labor law // Bulletin of LSU (Series "Economics, philosophy, law"), 1978.-№23. Issue 4.-P.71

${ }^{1}$ Gordon V.M. Grounds for the claim as part of the amendment of the claim. - St. Petersburg: 1902. - 129 p .; Kleinman A.F. The main questions of the theory of proof in the Soviet civil procedure. -M $\therefore$ Academy of Sciences of the USSR, 1950.-P.34-35.

${ }^{1}$ Imomov N.F. Terms and period of limitation in civil law. -Tashkent: TSU, 2005. -27 p. 